$\frac{\text { Jpn. J. Pharm. Health Care Sci. }}{\text { ノート } 33(1) 87-92(2007)}$

\author{
薬袋のユニバーサルデザイン \\ 丸山 徹 ${ }^{* 1}$, 古川真一 ${ }^{2}$, 吉田健二 ${ }^{2}$, 荒平光利 ${ }^{1}$, 佐藤弘希 ${ }^{1}$, \\ 岡山善郎 ${ }^{1}$, 山崎啓之 ${ }^{3}$, 森内宏志 ${ }^{3}$, 甲佐貴光 ${ }^{4}$, \\ 石塚洋一 ${ }^{4}$, 入倉 充 $^{4}$, 入江徹美 ${ }^{4}$ \\ ファーマダイワ \\ ファーマダイワ・レインボー薬局 ${ }^{2}$ \\ 崇城大学薬学部 \\ 熊本大学大学院医学薬学研究部 4
}

\title{
Universal Design for Medication Envelope
}

Toru Maruyama ${ }^{* 1}$, Shinichi Furukawa ${ }^{2}$, Kenji Yoshida², Mitsutoshi Arahira1, Hiroki Sato ${ }^{1}$,

Yoshiro Okayama ${ }^{1}$, Keishi Yamasaki ${ }^{3}$, Hiroshi Moriuchi ${ }^{3}$, Takamitsu Kosa',

Yoichi Ishitsuka $a^{4}$ Mitsuru Irikura ${ }^{4}$ and Tetsumi Irie ${ }^{4}$

Pharma Daiwa Co., Ltd. $^{1}$

Pharma Daiwa Co., Ltd. $\cdot$ Rainbow Pharmacy ${ }^{2}$

Faculty of Pharmaceutical Sciences, Sojo University ${ }^{3}$

Graduate School of Medical and Pharmaceutical Sciences, Kumamoto University ${ }^{4}$

$\left(\begin{array}{l}\text { Received May 25, } 2006 \\ \text { A ccepted November 15, 2006 }\end{array}\right)$

A medication envelope functions not only as a drug container but also as a means of providing basic information on the usage and dosage of a drug. We made a prototype medication envelope based on Universal Design (UD) with which administration instructions can be obtained through the senses of sight, hearing and touch. In addition to conventional printed information, the UD medication envelope is equipped with an audio playback device to provide prerecorded spoken instructions on administration. It also has Braille labels so that administration instructions may be checked using the sense of touch.

We performed a questionnaire survey of the usefulness of the UD medication envelope after it had been used by visually impaired patients, elderly patients as well as the families of patients, caregivers, nurses, and other individuals assisting pa tients in taking their drugs in the home health care setting. The results showed that the use of the UD medication envelope enabled the majority of patients to understand administration instructions better, which reduced mistakes in administration. They suggest that the UD medication envelope would help ensure that patients take drugs properly, thereby strengthening safety management, and would be useful in today's society in which there are large numbers or elderly and other types of patient having special needs with regard to understanding administration instructions.

Key words — universal design, medication envelope, drug administration, safety management, audio guidance, Braille label

\section{緒言}

薬局は , 多樣な疾患および生活スタイルの人が利用す る施設であり，年齢，性別，能力および疾病の程度によ る薬局の利用者を年齢・性別・機能・疾患等で表記した 場合，縦軸を年齢・性別，横軸を機能や疾患で示すと図 1 のようになる ${ }^{1-7)}$. 近年, 薬局の利用者の多樣なニー
ズに応える新たな手段として, ユニバーサルデザイン (UD)が注目を集めている1) . われわれは, 多樣な利用者 にやさしい薬局創りを目標として, 薬局サービスのハー ド,ソフトの両面にUD を導入した ユニバーサルファー マシー”を開設し，弚の活動内容について紹介してき だ) . ユニバーサルファーマシーでは," 医薬品情報を だれもが利用しやすいように五感に訴える”を概念と し, 情報のノーマリゼーションへ積極的に取り組んでい 


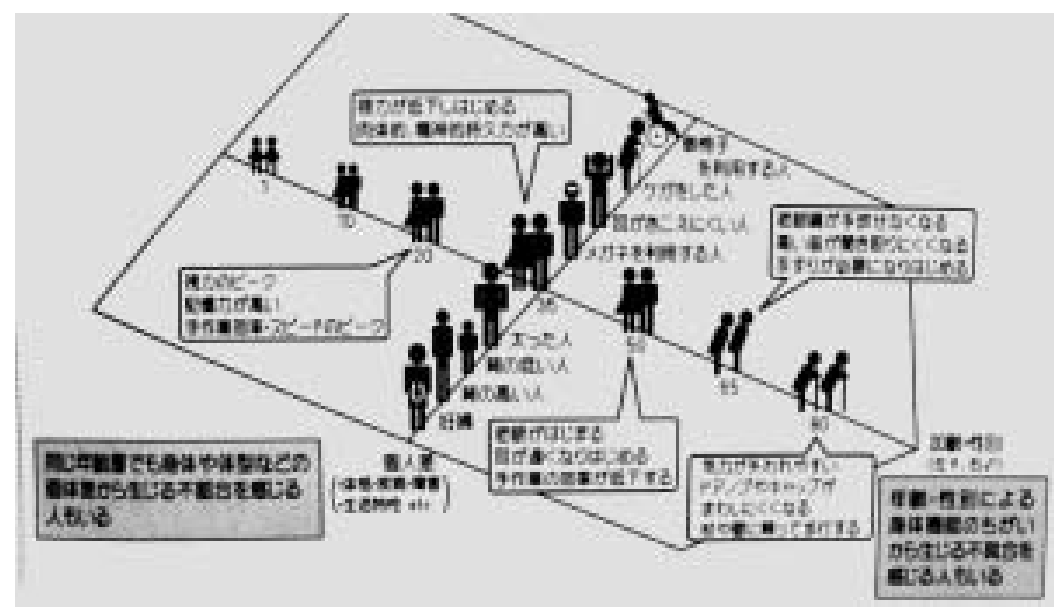

(薬事日報社と共同作成)

图 1.薬局利用者とユニバーサルデザインの関係 ${ }^{1-7 ~ 14-16) ~}$

る.これまで，“ビジュアル効果を活用した医薬品情報 提供”や“聴覚障害者に対する服薬指導を支援するため の手話学習システム”を開発し，关の有用性について報 告してきだ 10).

ところで, 薬袋はありふれた消耗品の一つであるが， 薬を入れる袋としての機能はもとより，用法・用量と いった服薬に関して最も大切な情報を提供する手段の一 つである．言い換えれば，服薬内容の誤記入や关れにと もなう不適切な解釈により，患者か医薬品を誤使用する ことによって予期せぬ副作用の出現や，逆に期待した治 療効果を得られないという事態も十分予想できる.事 実, 薬袋の誤記入が原因となった医療事故も報告されて いる1112).このような重要性にもかかわらず，古くから 薬袋を介した情報提供は文字のみで視覚に訴えるものが ほとんどで, 弱視や白内障などの視力障害者では情報収 集に間違いが生じやすい，高齢者の場合も，例えば，黄 斑症のように加齢にともない視力が低下したり，理解 力, 記憶力, 判断力も低下してくることがある. 谷のた め，従来の視覚による薬袋表示のみでは患者が服薬情報 をうまく活用できない場合もあり，結果として，視覚障 害者, 高齡者では情報の認識不足による誤服用やコンプ ライアンスの低下に影響を及ぼすことがある．

一方，居宅や施設で治療を受けている患者の場合，服 用は自立(自分で用意して自分で服用)しているケースも あるが, 家族や介護ヘルパーといった介護者や看護師に よって用意された薬剤を自分であるいは介助されながら 服用しているケースが多い，このような場合，服薬安全 管理は服薬介護者に依存しており，他者による二重確認 も実施されていないのか現状である. 兴のような状況下 では，危うく誤投薬し光うになったり，害際に誤投与を してしまうリスクは高く，これを放置すれば重大な医療 事故にも票がりかねない。したがって, 薬斉師は介護者
などによる誤投薬を防止するために介護者を指導してい く立場にあるが, 弚の情報提供手段は視覚に依存してい るのか現状である .

通常，利用者の情報理解度を向上させるためめには，同 じ情報を繰り返し発信するか，あるいはさまざまな感覚 情報を駆使した複数の手段による情報伝達が必要とされ ている.事実，UD を実践するための 7 原則の中にも゙ あ らゆる感覚による情報への配慮” という項目があるが， これは必要な情報か澴境や使い手の能力に関わらず，確 実に伝わるためにあらゆる感覚を駆使することを意味し ている ${ }^{13)}$. 例えば, 音声案内が付いた発券機や音, 光, 振動で着信を教えてくれる携帯電話などは身近な実用例 である．つまり，服薬の際にも，視覚以外の感覚を活用 することができるようになれば，誤服用のリスクが低下 し，ひいては適正使用の推進につながると思われる .

乥こで今回，弱視や白内障などの視力障害者，高齡者 への服薬情報提供あるいは居宅や施設で服薬補助者によ る服薬安全管理の向上を目的として, 従来の薬袋に極小 録音再生装置と点字シールを装着することにより “見 で，“聞いて”，“触って”，服薬内容を確認することが できるUD薬袋を開発した．また，アンケート調査によ り，弚の有用性について評価した .

\section{方法}

音声による服薬案内は, (姝メディカルケアセンターが 開発した小型録音再生装置(ボイスメッセージ)を用い た . 本装置は, 半径 $36 \mathrm{~mm}$, 厚さ $17 \mathrm{~mm}$, 重さ50g の円盤 状のプラスチックケースであり，マイクを利用して音声 を記録する録音部品と，スピーカーを介して音声を再生 する再生部品から構成されている(図2）．本装置は，20 秒間メッセージを録音可能であり，スイッチを押すとあ 


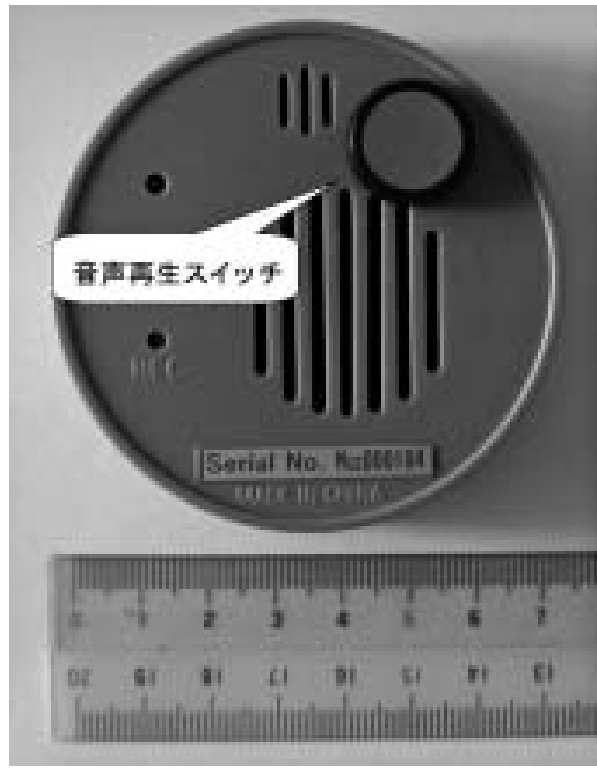

図 2 . ボイスメッセージの外観

らかじめ録音していた音声メッセージが再生される . 薬 袋は，ボイスメッセージを収納できるよう，ポケット付 に改良した．また，処方薬の量に対応できるよう，大き さが異なるものを 2 種類作成した .

服薬識別シールとしては，すでに服薬補助で実績があ るサンマーク・サンシール(㧣丸高三信堂)を採用し，原 則として，薬袋の左下隅に用法指示シールを貼付するよ うにした(図3).

UD 薬袋の有用性について, 視力障害者, 高龄者, 居 宅での服薬補助者(家族，介護ヘルパー，看護師)の28名 (平均年齢68 11歳，(男性19名，女性 9 名))を対象とし てアンケート調査を行った . 対象者の内訳は，視覚障害 者 2 名, 高齢者18名, 居宅における服薬補助者 8 名で あった . なお，高齢者の場合はいずれの対象者も程度の 違いはあるものの視覚や聴覚に機能低下か認められた . また, 居宅における服薬補助者 8 名のうちの3 名が同樣 な機能低下を自覚していた .

アンケートの内容は，(1これまで服薬を間違えたり， 服薬に際してヒヤリとしたことがあるか，(2)従来の薬袋 に比べ, 服薬内容がわかりやすくなったか, (3)従来の薬 袋に比べ，服薬を間違えにくくなったか，(4)今後もUD 薬袋を活用したいか，の4項目とした．また，対象者の うち，2名についてはコンプライアンスに問題があった ため，UD 薬袋の導入による影響を薬歴および患者イン タビューから調査した .

\section{結果と考察}

医薬品の適正使用を実践していくためには，正確な情 報提供が欠かせないことは言うまでもなく，弚のために

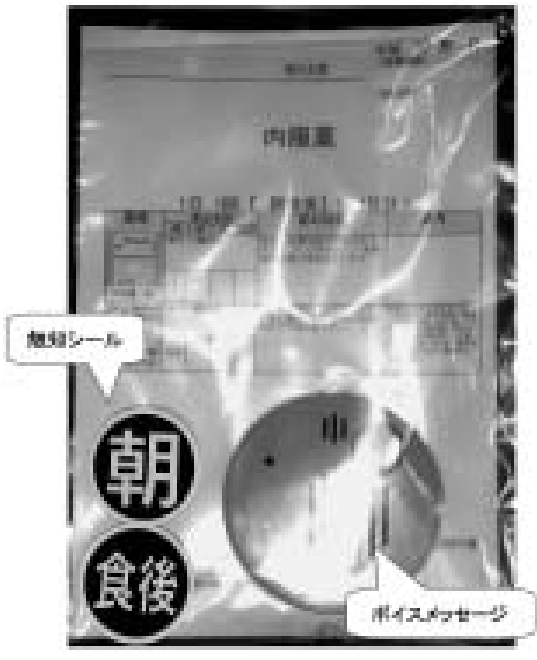

図 3. ユニバーサルデザイン薬袋の外観

は情報をUD 化し，すべての利用者が必要な情報を理解 できるように工夫する必要がある .

ところで, 薬袋は薬を収納するだけでなく，用法・用 量といった服薬に関する重要な基本情報を正確に伝達す るための機能も有している．つまり，薬袋情報の遵守は 医薬品適正使用を実践するための基本であるといっても 過言ではない，しかしながら現実には, 薬袋に関する検 討は，処方薬のボリュームに応じたサイズの選択などに 留まっており，患者の服薬能力に応じた情報提供につい てはほとんど配慮されていない .これまでの薬袋による 服薬情報提供は文字によるものがほとんどであり，正常 な視力を有する患者では適切な理解が可能であるが，視 力障害者や高齢者などでは光の情報の理解に正確さを欠 くケースも見受けられる. 平成11年度の厚生科学研究に よると，国内の視覚障害者(在宅者18歳以上)は全国で約 30 万人存在しており，关の約 2 割しか点字を理解できな いことが報告されている ${ }^{14)}$. また，高度な視力障害でな くても，60歳以上の高齢者の約 7 割が何らかの視力障害 (白内障など)を有していることが明らかにされてい $3^{1516)}$.つまり，今後の超高齢社会では，予想以上に薬 袋の記載内容が見えづらいと感じる人の割合が急激に増 えてくると予測できる .

一般に，対象とするものの使い方に関する必要な情報 が手に入らない場合, 自分自身の体験と知識に照らし合 わせて推測・判断するため，使用法を誤ってしまうケー スが多いといわれている.お光らく服薬に関するトラブ ルも同樣であり，服薬遵守や誤服用を防止するには，情 報を正確に伝達する方法が必要となる . この問題の解決 方法として，繰り返し情報を発信するか，あるいは2つ 以上の手段を組み合わせて提供することが有効であると いわれている ${ }^{133}$ ．したがって，服薬時に複数の伝達手 段が用意されていれば，能力が異なる多樣な患者や服薬 
補助者に対し同等に情報を確実に提供できるだけでなく， 患者や服薬補助者の不注意による飲み忘れについても対

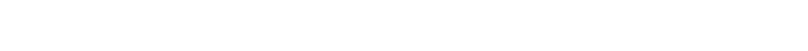
覚器から得られる情報が十分でなくても，弚れらを組み 合わせることで総合的に理解してもらうことが可能とな る.現在のところ，服薬ミスを最小限に少なくするため に，どの感覚を組み合わせることが有効であるのかは明 らかではない，最近では，視覚と聴覚を組み合わせる ケースが多く，音声ガイド機能を有する商品が数多く開 発されている、薬剤師業務においても散剂・水剂の監査 システムやスピーチオ (高齢者や視覚障害者に向けて開 発された SP コード専用読み取り装置)のような音声読 み上げによる情報提供システムなどに応用されている .

また, 眼で見ること以外に,「手で見る」すなわち触 覚を駆使することも情報を捕らえる観点から有用であ る.最近，大阪府薬斉師会と大阪府視覚障害者福祉協会 は，視覚障害者や高龄者が安全に医薬品を使用できるよ うにすることを目的に，色や突起した点で服用法を識別 可能な視覚障害者も共用できるバリヤフリーシールを作 成している.これにより，点字の読めない視覚障害者に もわかりやすく工夫されている .このような, 視覚障害 者と高齢者の双方に配慮したシールは全国でも初めての 試みであり，弚の成果に注目が集まっている．

このような背景のもと, 視覚, 聴覚, 触覚を組み合わ せて服薬補助を行うUD薬袋を開発した . 図 3 に今回開 発したUD 薬袋の外観を示す．まず，聴覚に対する情報 提供として，薬袋自体に取り付けられる，自由にメッ セージを録音することができる小型録音装置(ボイス メッセージ)を用いた．また, 触覚に対して, 点字の代 わりに多少の訓練でだれもが識別できる゙サンマーク・ サンシール”を利用した .これは，あらゆるタイプの視 力障害者のために開発された服薬識別シールであり，表 面に○や $\triangle$ などの簡単な記号を押し出し加工してあるた め，点字を読めない方でも，さわるだけで用法を判別す ることができる．これを图 $3 に$ にすように薬袋に貼付し た . 本薬袋の使用方法は簡便であり，服薬の際にボイス メッセージの音声再生ボタン(点字)をタッチすると，あ らかじめ録音されていた服用時点と服用量に関する音声 案内が流れ，同時に薬袋右下のサンマーク・サンシール で触認することができる．弚の結果，“見て”“"聞い て”,“触って”，服薬内容を確認することが可能とな り，視覚障害者や高齢者あるいは服薬補助者の服薬安全 管理の質的向上が期待される.

乥こで，UD薬袋の有用性を調査することを目的とし て，従来の視覚だけに訴える薬袋を利用していた視覚障 害者, 高齡者および居宅における服薬補助者を対象とし て, UD 薬袋を 3 力月以上利用してもらい, 導入後の変 化についてアンケート調査を行った . アンケートの内容
は，不注意あるいは理解不足による誤服用歴や危うく誤 服用し弚うになった経験，UD薬袋の使用感(わかりや すさや間違いにくさなど)，今後の使用継続についてで あった．アンケートの結果を図4にに示す．まず，服薬ミ スについては，回答者の多くが，誤服用あるいは危うく 誤服用し光うになった経験を有していることが判明し た“ UD 薬袋の導入により服薬内容がわかりやすくなっ たか?”という設問には, 回答者の 4 分の 3 が以前より わかりやすくなったと感じていた .弚れを反映しで, 以 前と比べ間違えにくくなったか?” という設問に対し て，約 7 割か従来の薬袋よりも間違えにくくなったと回 答していた .一方，あまり変わらないというケースも約 3割存在したが, 間違えやすくなったという回答はな かった“"今後もUD薬袋を活用したいか”との設問に 対しては，6割以上が利用したいとの回答であった。乥 の他の意見として “目がかすみ，薬袋の字が見えにく かったので，声で飲み方を教えてくれるのは間違えにく く助かる”といった意見や“"忙しい時は投薬した後に 間違っていないか心配になっていたが，この薬袋だと音 声で確認できるので安心できるようになっだ という介 護ヘルパーからの意見も寄せられた . 弚の一方で, 約 2 割がUD 薬袋は必要ないとの回答であった . 兴の内容 は “”飲み方はわかっているから確認することが面倒

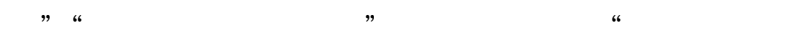
て小型にしてほしい”““音がもっとはっきりした方がよ い”など，さらに改善を望む意見があった．また，UD 薬袋の導入以前からコンプライアンスが不良であった 2 人の患者では, 導入後にコンプライアンスの向上が認め られた。

以上の結果から，今回作製したUD薬袋は, 視力障害 者, 高齢者, および居宅療養者の服薬介助における安全 管理において有用な手段である可能性が強く示唆され た .この原因として, 視覚以外の感覚を併用したこと や，メッセージを聞く，シールを触るという行動か習慣 化しやすいことなどが考えられた . 特に, 1 力月以上た つと習慣化しやすいように思われた ・ただし，このよう な確認作業の習慣化はミスを防止するためには有用であ るが, 兴の一方で, 継続による慣れも懸念される．弚の ため, メッセージのパターンを定期的に変更するなどの 工夫が長期に渡たる場合, 必要になるかもしれない，

また，ボイスメッセージを薬袋に装着することで, 音 質の低下か懸念されたが, メッセージの聞き取りに関し てはおおむね問題ないという回答が得られた .ただし， 一件ではあるが，もっと音声をはっきりしてほしいとい う意見も寄せられた . ボイスメッセージは装置の軽量化 や価格の都合上，再生音量が録音時の音量に依存してい るため, 再生時の調節ができなかったが, 今後は個々の 状況に応じて音量調節ができるようにするなどの更なる 


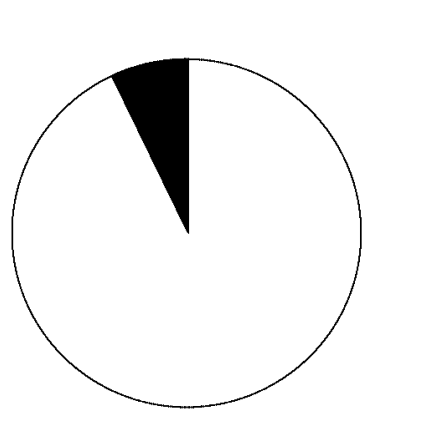

Q 1：薬を飲み間違えたことやヒヤリとした ことはありますか?

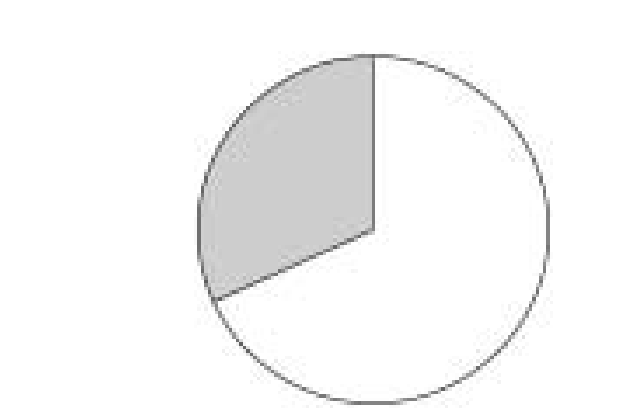

Q 3 : 新しい薬袋になって薬の飲み方を間違 えにくくなりましたか?

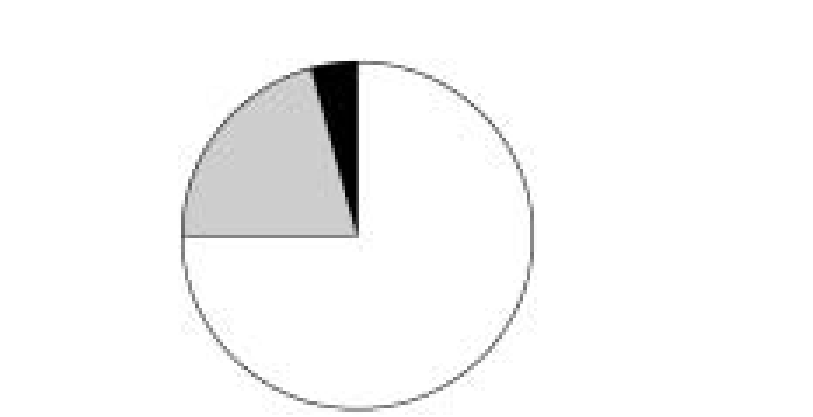

Q 2 : 新しい薬袋になって薬の飲み方がわか りやすくなりましたか?

図 4 .ユニバーサルデザイン薬袋に対するアンケート調査 $(n=28)$

改良か望まれる．さらに，薬斉師サイドからも“もつと 安価にしたほうがよい”,“さらに軽量化したほうがよ い”などのコメントも寄せられた . 今後 , これらの問題 については使用量の増加により改善していく必要がある . 今回の検討結果から，薬袋に音声ガイダンスを導入し て服薬を補助することは服薬安全管理における有効な手 法であることが明らかとなった . 現在 , 軽量化 , 高機能 化, 低コシスト化のために, 薬袋にIC チップを取り付 けたUD 薬袋の開発に取り組んでいる．これは，服薬に 関する情報を取り込んだICチップを薬袋に貼付し，情 報を服薬の際にユビキタス・コミュニケーターと呼ばれ る読みとり装置に表示させ，画面とボイスメッセージの 両面から服薬に関する情報を提供することができ，さら なる服薬情報のノーマリゼーションが期待できる .

薬袋をユニバーサルデザイン化することは，利用者の 視点から服薬支援および安全管理の実践を可能とし，今 後の高齢・多樣性社会では有用である . 特に , 今回検討 した聴覚や触覚などの視覚以外の感覚を加味すること で，視覚障害者，高齢者や居宅療養患者の服薬介助者の 誤服用防止，服薬遵守を支援することができ，近い将来 訪れるであろうユビキタス情報社会では, IT の活用が 日常化されることが予測できるため，五感に訴えた薬袋
のUD 化へIT 技術を積極的に活用し，さらなる服薬情 報のノーマリゼーションを推進していく必要があると考 える

\section{引用文献}

1) M.F. Story, J.L. Mueller, Measuring Usability : The Principles of Universal Design. In Designing for the 21st Century“ An International Conference on Universal Design of Information, Products, and Environments," J. Reagan, L. Trachtman, ed, NCSU, The Center for Universal Design, New Y ork, 126-129 (1998).

2) 福田忠彦“, 生体情報システム論”, 産業図書, 東京, 1995, pp. 180-194.

3) 近藤勉 “ ‘くわかる高齢者の心理” ,ナカニシヤ出 版，京都，2001, p. 24.

4) D.C. Park, N. Schwarz ““認知のエイジング入門編” , 北大路書房，京都，2004, pp. 160-170.

5) 徳田哲男 “ 講座・高齢社会の技術3生活の技術”, 日本評論社，東京，1995, pp. 45-52.

6) 東京都立大学体力標準値研究会 “”新・日本人の体 力標準値”, 不昧堂出版, 2000, pp. 150-168.

7) S. Kose," Dwelling Design Guidelines for A ccessibility in the Aging Society: A New Era in Japan?' Handbook of Japan-US Environment Behavior Research: 
Toward a Transactional A pproach, Wapner S. et al, Eds., Plenum, New Y ork, 25-42 (1997).

8) 丸山徹, 吉田健二, 岡山善郎, ユニバーサルデザイ ンと薬局サービス，薬事日報，9699, 26 (2003).

9) 丸山徹, 吉田健二, 古川真一, 荒平光利, 佐藤弘希, 吉田節，岡山善郎，山崎啓之，森内宏志，入倉充， 入江徹美，医薬品情報のユニバーサルデザイン(1)〜 ビジュアル効果を活用した医薬品情報提供の有用性 評価，医療薬学，30, 608-613 (2004).

10) 丸山徹, 長峰智子, 荒平光利, 佐藤弘希 , 吉田節， 吉田健二, 岡山善郎, 山崎啓之, 森内宏志, 入倉充, 小野眞理子, 入江徹美, 医薬品情報のユニバーサル デザイン(2)〜聴覚障害者の服薬指導支援用手話学 習システムの開発, 医療薬学，31, 435-444 (2005).

11）社団法人日本薬剂師会，新聞(主として一般紙)に報
道された医薬品に関する医療事故例一薬局・薬斉師 関連「薬局・薬斉師のための調剂事故防止マニュア ル」,日本薬斉師会杂倠誌， 53, 74 (2001).

12) 財団法人日本医療機能評価機構 - 医療事故防止セン ター，「医療事故情報収集等事業一第六回報告書」， 2006年9月13日, pp. 76-78.

13) 中川聡“, ユニバーサルデザインの教科書”,日経デザ イン編，日経 BP 社，東京，2002, pp. 94-115.

14) 内閣府“, 障害者白書”,国立印刷局，東京，2003, pp. 121-134.

15) 高橋広“, ロービジョンケアの実際”、医学書院，東 京 , 2002, pp. 128-132.

16) 三浦文夫“, 図説高齢者白書”, 全国社会福祉協議会出 版部，東京，2005, pp. 35-42. 